\title{
Most cited articles in the Archives of Toxicology: the debate about possibilities and limitations of in vitro toxicity tests and replacement of in vivo studies
}

\author{
H. M. Bolt · J. G. Hengstler
}

Published online: 6 November 2008

(C) Springer-Verlag 2008

Every year the Archives of Toxicology celebrate the most cited authors (Table 1). As expected apoptosis, metal toxicity, oxidative stress and regulatory toxicology represented hot topics. The editors would like to highlight two outstanding articles, written by O'Brien et al. (2006) and a review by Greim et al. (2006), because both articles demonstrate important aspects of the current debate about replacement of in vivo studies by in vitro tests. O'Brien and colleagues performed a large validation study about prediction of human hepatotoxicity by a human hepatoma cell line in vitro. Human hepatocytes and also hepatocyte cell lines are frequently used for in vitro studies of toxicity, drug metabolism and enzyme induction (Hewitt et al. 2007; Hengstler et al. 2000; Brulport et al. 2007). Many examples of excellent correlations between in vitro data with hepatocytes and the in vivo situation have been published (Gebhardt et al. 2003; Hengstler et al. 2000; Carmo et al. 2005). However, well-designed validation studies including sufficient numbers of substances are rare. O'Brien and colleagues used a standardized in vitro test with human HepG2 cells and analyzed a well-chosen battery of endpoints. The authors studied 243 compounds with varying degree of toxicity. Overall human toxicity potential was detected with $80 \%$ sensitivity and $90 \%$ specificity. This is an important study, and also the most cited article published in the Archives between 2006 and 2007. Considering the limitations of an in vitro system based on HepG2 cells, such as incomplete metabolic competence or toxicities mediated by other cell types than hepatocytes, the result is encouraging.

H. M. Bolt · J. G. Hengstler $(\bowtie)$

Institut für Arbeitsphysiologie an der Universität Dortmund, Leibniz Research Centre for Working Environment and Human Factors (IfADo), Ardeystrasse 67, 44139 Dortmund, Germany e-mail: hengstler@ifado.de
Without doubt well-validated in vitro tests, such as the human hepatocyte screening assay of O'Brien et al. can be used to identify substances with an increased potential to cause specific toxic effects, such as hepatotoxicity in the case of O'Brien's test strategy. This is indeed an important progress. However, two major limitations remain. First, an in vitro test using one particular primary cell type, such as the hepatocytes or a hepatocyte cell line, may have the potential to predict liver toxicity but not toxicity to other organs (which was of course not intended by the authors). Second, at the present state of the art in vitro studies only allow screening for specific hazardous properties but information about in vivo dose-response relationships and identification of NOELS cannot be obtained. This is where the review of Helmut Greim and further recognized European Toxicologists comes in (Greim et al. 2006). The authors discuss one of the problematic aspects of the new European chemicals legislation REACH according to which repeated dose studies may only be required for substances produced beyond $100 \mathrm{t} / \mathrm{year}$. This means that most of the substances will not be studied by repeated dose tests such as 28- and 90-day studies. The authors criticize that in the absence of such information the hazard identification will be incomplete. Alternative in vitro studies alone will not identify all relevant endpoints of in vivo toxicity and can not identify thresholds and NOELS. Therefore, the authors criticize that a premature replacement of in vivo tests primarily considers cost reduction and protection of animals, whereas the protection of human health and the environment are secondary. The editors feel that this is an important contribution to the recent debate. It also leads to the discussion to which extent and when we will be able to predict NOELS only by in vitro tests. The latter has recently been discussed in this journal by $\mathrm{Li}$ lienblum et al. (2008) and large EU projects focus on his 
Table 1 The 20 most cited articles in the Archives of Toxicology in 2006 and 2007

\begin{tabular}{|c|c|c|}
\hline No. & Author & Take home message \\
\hline 1 & O’Brien et al. 2006 & $\begin{array}{l}\text { Human hepatocytes in vitro predict human hepatotoxicity potential with high sensitivity and specificity in } \\
\text { a large validation study }\end{array}$ \\
\hline 2 & Stefanidou et al. 2006 & Physiological supplementation of zink reduces risk of age-related diseases \\
\hline 3 & Hwang et al. 2006 & The plant alkaloid berberine decreases Bcl-xL expression and causes apoptosis in hepatoma cells \\
\hline 4 & Boettcher et al. 2006 & The metabolic profile of acrylamide in humans is more similar to that of rats than of mice \\
\hline 5 & Reistad et al. 2006 & $\begin{array}{l}\text { The flame retardants DE-71 a pentabrominated diphenyl ether and hexabromocyclododecane have a } \\
\text { neurotoxic potential }\end{array}$ \\
\hline 6 & Barbosa et al. 2006a & $\begin{array}{l}\text { Lead exposure was associated with decreased nitric oxide formation which may explain lead associatec } \\
\text { increased cardiovascular risk }\end{array}$ \\
\hline 7 & Schrickx et al. 2006 & The mycotoxin ochratoxin A is secreted by the ATP-dependent membrane transporters MRP2 and BCRF \\
\hline 8 & Zhan et al. 2006 & Fluoride causes lipid oxidation and apoptosis in livers of pigs \\
\hline 9 & Li et al. 2006 & $\begin{array}{l}\text { Aristolochic acid I causes DNA strand breaks and cell cycle arrest in renal tubular epithelial cells which } \\
\text { may explain Aristolocic acid associated nephrotoxicity }\end{array}$ \\
\hline 10 & Wu et al. 2006 & Cigarette smoke exposure induces apoptosis in lungs of rats \\
\hline 11 & Greim et al. 2006 & $\begin{array}{l}\text { According to REACH repeated dose studies (28-day and 90-day studies) are only required beyond } 100 \mathrm{t} \\
\text { a. This is criticized, because alternative in vitro studies do not allow identification of all relevant } \\
\text { hazardous properties and do not give adequate information on NOELS }\end{array}$ \\
\hline 12 & Kim et al. 2007 & The metal transporters DMT1 and MTP1 play a key role in tissue cadmium accumulation \\
\hline 13 & Nampoothiri et al. 2007 & Cadmium and lead accumulate in the ovary of rats and induce lipid peroxidation \\
\hline 14 & M’Bemba-Meka et al. 2007 & Intracellular calcium is critical for nickel carbonate hydroxide induced genotoxicity \\
\hline 15 & Raulf-Heimsoth et al. 2007 & $\begin{array}{l}\text { Aerosols of bitumen cause irritative airway effects in exposed workers, as evidenced by increased } \\
\text { neutrophil counts and cytokine sputum concentrations in highly exposed individuals }\end{array}$ \\
\hline 16 & Barbosa et al. 2006b & Salivary lead is not an adequate biomarker for lead exposure \\
\hline 17 & Moto et al. 2006 & The non-genotoxic carcinogen dicyclamil induces oxidative stress in livers of mice \\
\hline 18 & Myhrer et al. 2006 & A new microinfusion technique allows a more detailed examination of anticonvulsant properties of drugs \\
\hline 19 & Yang et al. 2006 & Decane, undecane and dodecane are the major toxic hydrocarbons of jet fuels \\
\hline 20 & Montenegro et al. 2006 & $\begin{array}{l}\text { A polymorphism of the delta-aminolevulinic acid dehydratase gene (ALAD 1-2/2-2) identifies subjects } \\
\text { with increased susceptibility to lead exposure }\end{array}$ \\
\hline
\end{tabular}

task. In principle, all individual problems associated with in vitro in vivo extrapolation can be solved by pharmacokinetic modelling. However, the difficulty is complexity and the necessity to take into account all relevant factors of influence. In some future it may be possible to predict in vivo toxicity only by in vitro tests. We can not say whether this will be achieved in 15 or in 50 years. However, we can say for sure that this goal can not be achieved within 5 years. In the meantime as outlined by Greim and colleagues we have two possibilities (Greim et al. 2006): Continue the existing methods until reliable in vitro techniques are available or reduce the quality of hazard and risk evaluation which will probably be associated with adverse consequences for human health.

\section{References}

Barbosa F, Heloisa M, Rodrigues C et al (2006a) Evaluation of the use of salivary lead levels as a surrogate of blood lead or plasma lead levels in lead exposed subjects. Arch Toxicol 80:633-637
Barbosa F, Sertorio JTC, Gerlach RF et al (2006b) Clinical evidence for lead-induced inhibition of nitric oxide formation. Arch Toxicol 80:811-816

Boettcher MI, Bolt HM, Drexler H et al (2006) Excretion of mercapturic acids of acrylamide and glycidamide in human urine after single oral administration of deuterium-labelled acrylamide. Arch Toxicol 80:55-61

Brulport M, Schormann W, Bauer A, Hermes M, Elsner C, Hammersen FJ, Beerheide W, Spitkovsky D, Härtig W, Nussler A, Horn LC, Edelmann J, Pelz-Ackermann O, Petersen J, Kamprad M, von Mach M, Lupp A, Zulewski H, Hengstler JG (2007) Fate of extrahepatic human stem and precursor cells after transplantation into mouse livers. Hepatology 46:861-870

Carmo H, Hengstler JG, de Boer D, Ringel M, Remião F, Carvalho F, Fernandes E, dos Reys LA, Oesch F, de Lourdes Bastos M (2005) Metabolic pathways of 4-bromo-2, 5-dimethoxyphenethylamine (2C-B): analysis of phase I metabolism with hepatocytes of six species including human. Toxicology 206:75-89

Gebhardt R, Hengstler JG, Müller D, Glöckner R, Buenning P, Laube B, Schmelzer E, Ullrich M, Utesch D, Hewitt N, Ringel M, Hilz BR, Bader A, Langsch A, Koose T, Burger HJ, Maas J, Oesch F (2003) New hepatocyte in vitro systems for drug metabolism: metabolic capacity and recommendations for application in basic research and drug development, standard operation procedures. Drug Metab Rev 35:145-213 
Greim H, Arand M, Autrup H et al (2006) Toxicological comments to the discussion about REACH. Arch Toxicol 80:121-124

Hengstler JG, Utesch D, Steinberg P, Platt KL, Diener B, Ringel M, Swales N, Fischer T, Biefang K, Gerl M, Böttger T, Oesch F (2000) Cryopreserved primary hepatocytes as a constantly available in vitro model for the evaluation of human and animal drug metabolism and enzyme induction. Drug Metab Rev 32:81-118

Hewitt NJ, Lechón MJ, Houston JB, Hallifax D, Brown HS, Maurel P, Kenna JG, Gustavsson L, Lohmann C, Skonberg C, Guillouzo A, Tuschl G, Li AP, LeCluyse E, Groothuis GM, Hengstler JG (2007) Primary hepatocytes: current understanding of the regulation of metabolic enzymes and transporter proteins, and pharmaceutical practice for the use of hepatocytes in metabolism, enzyme induction, transporter, clearance, and hepatotoxicity studies. Drug Metab Rev 39:159-234

Hwang JM, Kuo HC, Tseng TH et al (2006) Berberine induces apoptosis through a mitochondria/caspases pathway in human hepatoma cells. Arch Toxicol 80:62-73

Kim DW, Kim KY, Choi BS et al (2007) Regulation of metal transporters by dietary iron, and the relationship between body iron levels and cadmium uptake. Arch Toxicol 81:327-334

Li Y, Liu ZH, Guo XH et al (2006) Aristolochic acid I-induced DNA damage and cell cycle arrest in renal tubular epithelial cells in vitro. Arch Toxicol 80:524-532

Lilienblum W, Dekant W, Foth H, Gebel T, Hengstler JG, Kahl R, Kramer P-J, Schweinfurth H, Wollin K-M (2008) Alternative methods to safety studies in experimental animals: role in the risk assessment of chemicals under the new European Chemicals Legislation (REACH). Arch Toxicol 82:211-236

M'Bemba-Meka P, Lemieux N, Chakrabarti SK (2007) Role of oxidative stress and intracellular calcium in nickel carbonate hydroxide-induced sister-chromatid exchange, and alterations in replication index and mitotic index in cultured human peripheral blood lymphocytes. Arch Toxicol 81:89-99

Montenegro MF, Barbosa F, Sandrim VC et al (2006) A polymorphism in the delta-aminolevulinic acid dehydratase gene modifies plasma/whole blood lead ratio. Arch Toxicol 80:394-398
Moto M, Umemura T, Okamura M et al (2006) Possible involvement of oxidative stress in dicyclanil-induced hepatocarcinogenesis in mice. Arch Toxicol 80:694-702

Myhrer T, Nguyen NHT, Enger S et al (2006) Anticonvulsant effects of $\operatorname{GABA}(\mathrm{A})$ modulators microinfused into area tempestas or substantia nigra in rats exposed to soman. Arch Toxicol 80:502507

Nampoothiri LP, Agarwal A, Gupta S (2007) Effect of co-exposure to lead and cadmium on antioxidant status in rat ovarian granulose cells. Arch Toxicol 81:145-150

O'Brien PJ, Irwin W, Diaz D et al (2006) High concordance of druginduced human hepatotoxicity with in vitro cytotoxicity measured in a novel cell-based model using high content screening. Arch Toxicol 80:580-604

Raulf-Heimsoth M, Pesch B, Schott K et al (2007) Irritative effects of fumes and aerosols of bitumen on the airways: results of a crossshift study. Arch Toxicol 81:35-44

Reistad T, Fonnum F, Mariussen E (2006) Neurotoxicity of the pentabrominated diphenyl ether mixture, DE-71, and hexabromocyclododecane (HBCD) in rat cerebellar granule cells in vitro. Arch Toxicol 80:785-796

Schrickx J, Lektarau Y, Fink-Gremmels J (2006) Ochratoxin A secretion by ATP-dependent membrane transporters in Caco-2 cells. Arch Toxicol 80:243-249

Stefanidou M, Maravelias C, Dona A et al (2006) Zinc: a multipurpose trace element. Arch Toxicol 80:1-9

Wu CH, Lin HH, Yan FP et al (2006) Immunohistochemical detection of apoptotic proteins, p53/Bax and JNK/FasL cascade, in the lung of rats exposed to cigarette smoke. Arch Toxicol 80:328336

Yang JH, Lee CH, Monteiro-Riviere NA et al (2006) Toxicity of jet fuel aliphatic and aromatic hydrocarbon mixtures on human epidermal keratinocytes: evaluation based on in vitro cytotoxicity and interleukin-8 release. Arch Toxicol 80:508-523

Zhan XA, Wang M, Xu ZR et al (2006) Evaluation of caspasedependent apoptosis during fluoride-induced liver lesion in pigs. Arch Toxicol 80:74-80 